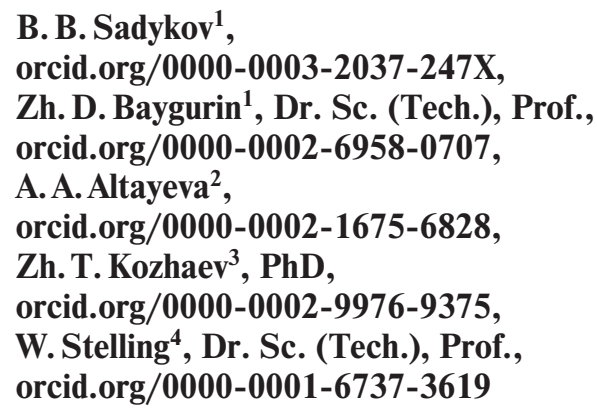

1 - Satbayev University, Almaty, the Republic of Kazakhstan, e-mail: batyrkhan_sadykov@mail.ru

2 - Institute of Mining named after D. A. Kunaev, Almaty, the Republic of Kazakhstan, e-mail: a.aselya 92@mail.ru

3 - Kazakh National University al-Farabi, Almaty, the Republic of Kazakhstan

4 - Technische Hochschule Georg Agricola, Bochum, Germany

\title{
NEW APPROACH TO ZONE DIVISION OF SURFACE OF THE DEPOSIT BY THE DEGREE OF SINKHOLE RISK
}

Purpose. Development of a new method of zoning the surface of the field according to the degree of rock weakness, which is based on the energy criterion, which is determined by the difference in the potential gravitational energy of the rock element between the states of unstable and stable equilibrium.

Methodology. Experimental graphical analytic methods and mathematical modeling are applied.

Findings. A method of zonal regionalisation of the earth's surface of the deposit according to the degree of sinkhole risk, taking into account the fracturing of rocks and the distribution of rock pressure in relation to the terrain is proposed. Verification of the results of the analysis of previously performed methods and theoretical propositions to substantiate the anisotropy of the density of the rock massif is carried out. The new method for determining the stress-strain state of a mountain massif considers the geoenergy of its density.

Originality. A new method has been developed for determining the stress-strain state of a rock mass through the difference in geo-energy between the state of stable and unstable equilibrium of a mass element.

Practical value. The developed method made it possible to increase the accuracy of the construction of the situational map of the field zoning according to the energy criterion by $15-20 \%$.

Keywords: geomonitoring, space radar interferometry, digital map, zoning criterion, potential energy

Introduction. For many decades, there has actively been conducted and developed research in the field of displacement of the earth's surface and rock mass in the development of deposits [1]. However, in the process of extracting reserves of solid minerals from the subsoil by the underground method, various natural and man-made processes occur - activation of tectonic disturbances, subsidence (contraction, muld) of the earth's surface, the collapse of mine workings, which can be abnormal or lead to negative consequences up to the occurrence of emergency situations [2].

Problem statement. Underground mining of mineral deposits is accompanied by progressive discontinuity disturbances and structural changes in the properties of the rock mass, activation of existing and manifestation of new geomechanical processes against the background of reactionary changes in its stress-strain state.

The intensity, depth and scale of mining operations, as well as the duration of development of the field lead to an increase in the magnitude of the displacement of rocks. At the same time, large volumes of the massif are displaced the geometry of voids in the massif changes due to the growth of the volume of destroyed rocks (pillars, roof, overlying thickness, and sometimes the earth's surface).

At the stage of completion of ore deposits, the depletion of ore reserves, and a stable tendency to reduce the content of the useful component in crude ore, require in this regard, an increase in the extraction of mineral raw materials and necessitate the involvement of ore reserves remaining in the undermined rock mass, including those supporting low-grade thick pillars.

As the experience of developed countries has shown, an increase in the intensity of development of mineral deposits, which is associated with technological progress, is accompanied by manifestations of deformation processes that do not fit

(C) Sadykov B. B., Baygurin Zh.D., Altayeva A.A., Kozhaev Zh.T., Stelling W., 2019 into modern ideas about the shift of a rock mass. So, for example, at present in China, South Africa, Chile, Ukraine, Russia and Kazakhstan (Shachterskaya-Glubokaya mine, Mponeng, Western Deep Levels Mine, Witwatersrand, Krasnoyarskaya SUEK-Kuzbass OJSC, Kazakhmys JSC, etc.) there occur failures on the earth's surface, not predicted by regular methods $[3,4]$. In addition, the rate of extraction of minerals has sharply increased, which also raises questions about the assessment of the reaction of the earth's surface to these effects. This trend is global in nature, accompanied by an increase in the intensity of negative manifestations on the earth's surface in the territories of development of mineral deposits $[5,6]$.

Different geological conditions of occurrence of mineral deposits, the variety of physical processes occurring in the rock mass, various types of applied loads to the rock mass, numerous geometric forms of mine workings, changing physical, mechanical and strength properties of rocks create specific conditions for the analysis of stress-strain state (SSS) of the rock massif. The importance of this analysis is dictated by the problems associated with the manifestation of rock pressure, which can be realized in the form of physical processes of loss of stability of ores, significant deformation of rocks and can lead to the destruction of inter-chamber pillars and the formation of sinkholes on the earth's surface [7, 8]. In this regard, the development of methods of zonal regionalization of the surface of the deposit by the degree of attenuation, as part of the analysis of the structure of the rock massif, is of considerable interest. Therefore, the purpose of this article is to develop a new method of zonal regionalization of the surface of the deposit according to the degree of attenuation, which is based on the energy criterion determined by the difference in the potential energy of gravity of the rock mass element between the states of unstable and stable equilibrium.

Critical analysis. The application of existing forecasting methods is based on an analytical approach. They provide detailed information about the forms of genesis and patterns of 
placement of violations, changes in the properties and condition of the rock massif, allow us to make quantitative and qualitative assessments of the conditions of occurrence of violations, the degree of disturbance, to make assumptions about the directions and intensity of such processes within local areas [9]. The main disadvantages of these methods are their limitations and lack of reliability.

Improvement of existing and creation of new methods is aimed at increasing the reliability and validity of the assessment of the location and parameters of the violation, the possibility of their prediction.

Zoning criteria for each deposit are established on the basis of retrospective cause-and-effect analysis of the occurring geodynamic events, taking into account the structural features of the rock mass (geological structure, tectonic disturbance, fracturing, applied development systems), physical and mechanical properties and stress-strain state of the rock mass. The criterion is accepted uniform throughout the field.

At the same time, within the field itself, at different sites, the properties of the massif and its condition can differ significantly, which in a certain way affects the uniqueness of the criterion of the zoning method and naturally reduces its accuracy. Therefore, when building the criterion of new methods and improving existing ones, developers strive to bring in accordance with these differences the values included in the criterion, making it correct throughout the field. In the Zhezkazgan field, a method was used to determine the collapse forecast, based on the well-known fact that the parameters of the geodynamic event and the time of its development depend mainly on the height of the mined area and the overlying rocks from the boundary of the mined space to the surface $\mathrm{H}$ and the output power $\mathrm{m}$. The collapse forecast criterion was taken to be $H / m<10$.

The main disadvantage of the method is that the obtained criterion is determined only by the geometric parameters $H$ and $m$. At the same time, it is known that the parameters of the geodynamic event mainly depend on the pressure on the mined area from the overlying rocks, proportional to their weight, determined by the density distribution in this volume.

Therefore, in areas of the massif, which are located in different parts of it, but at the same depth from the surface, due to the difference in density, the pressure is different and, therefore, the expected geodynamic events will differ significantly in all parameters. At the same time, the $\mathrm{h} / \mathrm{m}$ criterion established in the method for these sites is the same.

In the method [10] to account for the anisotropy of the density of the massif, $H$ in the criteria is replaced by $H_{d r}$ - the density-reduced depth of the overlying rocks. The criterion for zoning is the value of $H_{d r} / \mathrm{m}$. In this form the criterion is density invariant and thus correct throughout the field.

In another method [11, 12], such values as $H$ and $m$ are replaced by the vertical component $\left(Z_{c}\right)$ coordinates of the center of gravity of the column of the array extending vertically up to the surface of the Deposit.

The center of gravity characterizes the distribution of mass in the column, and its displacement in the process of mining its redistribution throughout the depth of the massif. In the process of such changes due to internal and external factors the instability of the system is observed. Based on these physical prerequisites, changes in the position of the center of gravity of the rock massif in the column can serve as a local indicator of the formation of anomalous regions. The zoning criterion is the value of the relative displacement of the vertical component of the coordinate of the center of gravity of the column array [13].

Methods. Different types of geomechanical processes, the intensity and direction of their development in the mountain range depend on a variety of external and internal factors. Despite the fundamental difference in the influence of these factors on the processes of transition of the array from one state to another, they are united by a common factor of influence on the processes determined by the energy parameters of the system [14, 15]. First of all, this is the redistribution of the total energy within the volume of the array and by type of energy.

Energy is a universal quantitative measure of the movement and interaction of bodies [16]. Despite the fundamental difference in the influence of these factors on the processes of transition of the array from one state to another, they are united by a common factor of influence on the processes determined by the energy parameters of the system. The development of deposits is accompanied by the activation of these processes in the rock massif due to the violation of its continuity and the desire of the system to return to a new state of stable equilibrium. Therefore, the energy indicators of the state of the rock mass can serve as parameters characterizing the general physical laws of the course of mine mechanical processes, the basis of which is mechanical motion. The energy source, along with the potential energy of elastic deformation, accumulated by the array in a stress-strain state in large quantities, is an excess of the potential energy of gravity of the sections of the array located above the workings. With the increase in the amount of space mined, the intensity of such processes increases and the more energy is required to maintain them. Being in a state of unstable equilibrium, the sections are motivated to fill the worked out space and go into a state of stable equilibrium corresponding to a minimum of energy. The greater the energy difference of the states is, the greater the probability of such a transition is, proportional to the volume of workings and the depth of their occurrence. Thus, the difference of potential energy between unstable and stable states can serve as one of the local indicators of the degree of potential danger of the state of the array section. On this principle, a method for zoning the surface of the deposit according to the degree of attenuation is constructed, in which the potential energy difference between the states of unstable and stable equilibrium of the array element is chosen as an energy criterion [17]. The availability of the necessary data in the geological and mining technical documentation of the field, the simplicity of calculations and the effectiveness of zoning objectively indicate the prospects of using the method, and its wide possibilities for analyzing the stress-strain state of the mountain range and predicting crisis situations. At the same time, verification of the results of zonal regionalization with the data obtained by the methods of space radar interferometry showed a significant discrepancy for the areas of the field with a pronounced heterogeneity of layers in density. This is explained by the fact that the potential gravitational energy underlying the zoning energy criterion [18] is largely determined by the distribution and redistribution of the density of the massif within the volume of the deposit. Therefore, in the calculation of the energy criterion it is necessary to take into account the density anisotropy.

To take into account the heterogeneity of the rock massif in density when calculating the energy criterion of zonal regionalization, a model of the deposit with a layer-by-layer distribution of the rock massif in density is proposed.

For this purpose, according to geological data and mining documentation, the layer-by-layer distribution of the rock massif by density is determined. Within each layer the density is considered constant. When calculating the criterion, a mass element in the form of a column of rock mass extending vertically down from the surface of the day to the base of the Deposit is considered (Fig. 1). The base of the Deposit is taken as the zero counting of the potential energy $(z=0)$. The zoning criterion is the potential energy difference between the unstable $P_{u s}$ (Fig. $\left.1, b\right)$ and the stable $P_{s}$ (Fig. 1,c) states of the column. The potential energy $P_{0}$ of the column in the initial (beginning) state is equal to (Fig. 1, $a$ ) [19]

$$
P_{0}=M g Z_{c 0},
$$

where $M$ is mass of a column; $g$ is gravity acceleration; $Z_{c 0}$ is the vertical component of the coordinate of the center of mass 


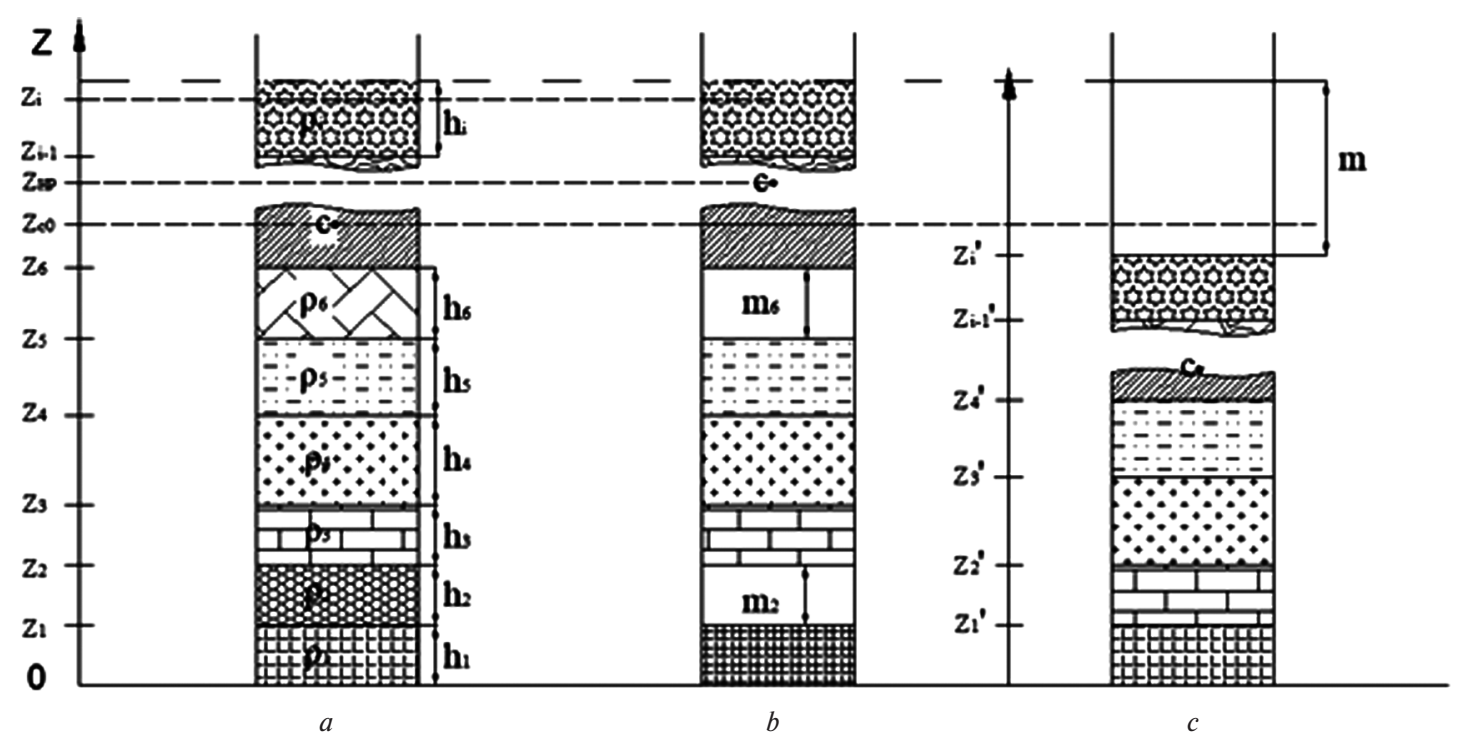

Fig. 1. Elements of the rock massif:

$a$ - in initial state, $c$ - mass center; $Z_{i}-$ coordinates of upper border of an $i$-layer; $\rho_{i}-$ the density in the interval of $h_{i}$ column; $b-$ in a state of unstable equilibrium, $m_{2}, m_{6}-$ mine capacity; $c-$ in a state of stable equilibrium $m=\sum m_{i}-$ the total capacity of the mine; $z_{2}-z_{2}^{\prime}=z_{3}-z_{3}^{\prime}=z_{4}-z_{4}^{\prime}=m_{2} ; \quad z_{7}-z_{7}^{\prime}=z_{8}-z_{8}^{\prime}=\ldots z_{i}-z_{i}^{\prime}=m_{2}+m_{6}$

and simultaneously the distance of the center of mass from the zero energy level.

The mass of the $i^{\text {th }}$ layer of the column $M_{i}$ is equal to

$$
M_{i}=S \rho_{i}\left(Z_{i}-Z_{i-1}\right)=S \rho_{i} h_{i},
$$

where $h_{i}=\left(Z_{i}-Z_{i-1}\right)$ is the capacity of the $i^{\text {th }}$ layer; $S$ is the base area of the column.

Accordingly, the mass of the entire column $M$ in the initial state is equal to

$$
M=\sum M_{i}=S \sum \rho_{i} S\left(\mathrm{Z}_{i}-\mathrm{Z}_{i-1}\right)=S \sum \rho_{i} h_{i} .
$$

Since the density in the volume of each layer is constant, its vertical component of the center of mass $Z_{c i}$ coincides with the geometric center of the layer

$$
Z_{c i}=\frac{1}{2}\left(Z_{i}+Z_{i-1}\right)
$$

By definition, the vertical component coordinates the center of mass of the column in the initial state

$$
Z_{c 0}=\frac{\sum M_{i} Z_{c i}}{\sum M_{i}} .
$$

Using $Z_{c 0}, Z_{c i}$ and $M$, the expression $M_{i}$ takes the form

$$
Z_{c 0}=\frac{\frac{1}{2} \sum \rho_{i}\left(Z_{i}^{2}-Z_{i-1}^{2}\right)}{\sum \rho_{i}\left(Z_{i}-Z_{i-1}\right)} .
$$

Or, given that the difference of squares $z_{i}^{2}-Z_{i-1}^{2}=\left(Z_{i}+\right.$ $\left.+Z_{i-1}\right)\left(Z_{i}-Z_{i-1}\right)$, using $M_{i}$ and $M$

$$
Z_{c 0}=\sum \rho_{i} h_{i} Z_{c i} / \sum \rho_{i} h_{i} .
$$

The potential energy of the $i^{\text {th }}$ layer of the column taking into account $P_{0}, M_{i}$ is determined by the expression

$$
P_{0 i}=S g \rho_{i} h_{i} Z_{c i} \text {. }
$$

At the same time, the potential energy of the entire column $P_{0}$ will be equal to the sum of the potential energies of the layers $P_{0 i}$

$$
P_{0}=\sum P_{0 i}=g S \sum \rho_{i} h_{i} Z_{c i}
$$

To calculate the energy difference chosen as the zoning energy criterion, consider the sequential transition of the column from the initial state of stable equilibrium with energy $P_{0}$ to the state of unstable equilibrium, according to the results of mining operations at the current time, with energy $P_{u s}$ and the subsequent transition to the virtual state of stable equilibrium with energy $P_{s}$ (Fig. 1).

In the process of mining the mass of the column and its energy are reduced in proportion to the volume of the developed space and lowering the position of the center of mass. The energy lost $P_{m}$ is equal to

$$
P_{m}=S g \sum \rho_{i} m_{i} Z_{c i},
$$

where $m_{i}$ is the capacity of the $i^{\text {th }}$ layer $\left(m_{i}=h_{i}\right) ; Z_{c i}$ is the center of mass of mine before the beginning of development.

The energy of the column in a state of unstable equilibrium is determined by the energy difference between $P_{0}$ and $P_{m}$

$$
P_{u s}=P_{0}-P_{m}=S g \sum_{\substack{i \\ i \neq j}} \rho_{i} h_{i} Z_{c i} .
$$

In the process of transition to a state of stable equilibrium, the overlying layers of the rock tend to fill the voids, which leads to a downward shift of the vertical component of the coordinate from the center of mass of the entire column. In this case, the center of mass of each layer falls down by the value of the total capacity of the mines lying below (Fig. 1, $b$ ).

Taking into account the constancy of the density and capacity of the layers from, considering the displacement of their center of mass, we obtain the formula for determining the value of the potential gravitational energy of the column in a stable equilibrium state of $P_{s}$ on the example of the intersection of two mines $\mathrm{m} 2$ and $\mathrm{m} 6$ of the column (Fig. 1,c)

$$
P_{s}=S g \rho_{1} h_{1} Z_{c 1}+\sum_{i-3}^{6} \rho_{i} h_{i}\left(Z_{c i}-m_{2}\right)+\sum_{i=7}^{k} \rho_{i} h_{i}\left(Z_{c i}-m_{2}-m_{6}\right) .
$$
and $P_{m}$

The energy difference of the two states is found from $P_{0}$

$$
\Delta P=P_{u s}-P_{s}=\sum_{i=3}^{6} \rho_{i} h_{i} m_{2}+\sum_{i=7}^{k} \rho_{i} h_{i}\left(m_{2}+m_{6}\right),
$$

where $k$ is the number of layers per column. 
The criterion of the zoning method is the value of the relative change in energy $\varepsilon$

$$
\varepsilon=\frac{\Delta P}{P_{0}}=\frac{\sum_{i=3}^{6} \rho_{i} h_{i} m_{2}+\sum_{i=7}^{k} \rho_{i} h_{i}\left(m_{2}+m_{6}\right)}{\sum \rho_{i} h_{i} Z_{c i}} .
$$

The proposed method is carried out as follows: a coordinate grid is drawn on the field plan $(x, y)$. The bottom horizon of the field is taken as the beginning of the count on the $Z$ axis (the $Z$ axis is directed vertically upwards). Using, geological and mining data for the entire area of the field or for its individual sections determine at each point of the surface of the potential energy of the array element in the form of a column.

From the beginning, the potential energy of the $P_{0}$ column in the initially untouched rock massif is determined if possible, otherwise the untouched massif is achieved by calculating the known mass of the extracted ore and the geometric dimensions of the mine. The next step is the potential energy of the column $P_{u s}$ and the potential energy in the virtual stable equilibrium state $P_{s}$. Then for each point of the plan the difference $\Delta P=P_{u s}-P_{s}$ is found and the results are submitted to the plan. On the plan by extrapolation, connecting points with the same values $\Delta P$ we build isolines, dividing the surface of the deposit into certain zones. The most dangerous areas are those with a maximum value of $\Delta P$. The degree of danger of the zone depends on its width and the magnitude of the difference $\Delta P$ with neighboring zones (from the gradient $\Delta P$ ).

For the convenience of zoning, the value of the relative change in the potential energy $\varepsilon$ is taken as a criterion.

In the plan, by means of extrapolation connecting points with the same values $\varepsilon$, isolines are constructed dividing the surface of the deposit into certain zones (by analogy with $\Delta P$ ) (Fig. 2).

The most dangerous are the zones with an increased value of $\varepsilon$, corresponding to the largest volumes of workings and depth of occurrence. The degree of danger of the zone depends on its area and the difference $\varepsilon$ of neighboring zones (on the gradient $\varepsilon$ ). The zonal surface of the deposit covered by isolines can be characterized by the effective radius $R_{e f f}-$ the radius of the circle whose area is equal to the area of the zone. Accordingly, the value of the gradient $\varepsilon$ is determined by the ratio of the difference of the values $\varepsilon$ of neighboring zones to the difference of their effective radii

$$
\vec{\gamma}=\operatorname{grad} \varepsilon \frac{\varepsilon_{i}-\varepsilon_{i-1}}{R i-R_{i-1}} .
$$

The vector $\vec{\gamma}$ indicates the direction of the maximum change in potential energy and possible displacement of the earth's surface [13].

Comparative analysis of the zoning results showed a significant increase in the accuracy of the proposed method with analogs based on their verification with the data of space differential radar interferometry $[14,15]$.

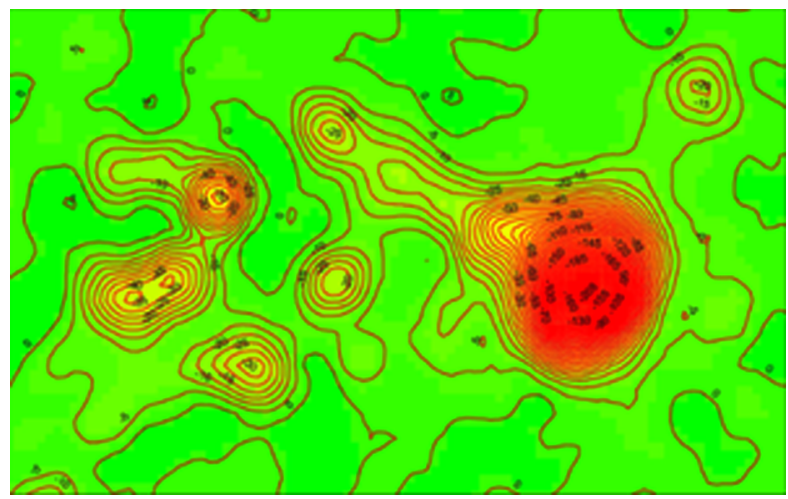

Fig. 2. Areas of greatest risk to the surface of the field
Conclusions. Thus, the anisotropy of the density of rock massif in the calculation of the energy criterion improves the accuracy of the zoning of the earth's surface and allows expanding the capabilities of the method to analyze the stressstrain state of rock mass and prediction of crisis situations. A new method for determining the stress-strain state of a mountain massif through the geoenergy difference between the state of stable and unstable equilibrium of an element of the massif has been developed.

Notice. This article is based on the results of scientific research work on the topic "Development of a forecast system and Geomonitoring methods for displacements of the mountain massif in hazardous areas of the earth's surface in the development of subsoil on the basis of innovative methods of GIS technology” No. AP05133929.

\section{References.}

1. Sashyrin, A. D. (2018). Geomechanical processes and phenomena defining the safety and efficiency of mineral resource management, regularities of their development. Problemy nedropolzovaniia, (3), 21-27.

2. Kashnikov, Yu.A., Gladyshev, S.V., Ashihmin, S.G., \& Popov, S. N. (2010). Geomechanical and geodynamic problem accompanying development of hydrocarbon deposit. $\mathrm{Za}$ piski Gornogo instituta, 188, 153-157.

3. Issabek, T. K., Dyomin, V. F., \& Ivadilinova, D. T. (2019). Methods for monitoring the earth surface displacement at points of small geodetic network under the underground method of coal development. Naukovyi Visnyk Natsionalnoho Hirnychoho Universytetu, (2), 13-20. https://doi.org/10.29202/ nvngu/2019-2/2.

4. Panzhin, A.A., Sashurin, A.D., Panzhina, N.A., \& Mazurov, B.T. (2016). Geodetic support of geodynamic monitoring of subsurface use facilities. Vestnik STUGiT, 4(36), 26-39. 5. Yaobin Sheng, Linlin Ge, Yunjia Wang, \& Chris Rizos (2012). Differential radar interferometry and its application in monitoring underground coal mining-induced subsidence. Retrieved from https://www.researchgate.net/publication/228376970 Differential_radar_interferometry and_its application_in_monitoring_underground_coal_mining-induced_subsidence.

6. Ge Linlin, Rizos Ch., \& Hsing-Chung Chang (2004). Satellite radar interferometry for mine subsidence monitoring. Retrieved from https://www.researchgate.net/publication/228847412 Satellite radar_interferometry for_mine subsidence monitoring.

7. Bozhko, V. G., Griniuk, B.A., \& Chirva, A. I. (2009). Use of modern technologies while monitoring deformations of rocks and the earth's surface in the zone of influence of underground extraction in Krivbass. Naukovi pratsi Donetskoho natsionalnoho tehnichnoho universytetu. Seriia: Hirnychoheolohichna, 9(143), 1-6.

8. Panzhin, A.A. (2000). Observation of the displacement of the Earth's surface at mining enterprise using GPS, (11), 196203.

9. Shustov, D. V., \& Yermashov, A. O. (2012). Forecast of displacement and deformation of rock massif of Tishinskii deposit by the finite element method and discrete element method. Vestnik PNIPU. Geologiia. Neftegazovoe i gornoe delo, (5), 89-96.

10. Baigurin, Zh. D., Imansakipova, B. B., Altaeva, A. A., \& Sadykov, B. B. (2018). Energy criterion of zone division of surface of the deposit by the degree of caving risk. Collected papers further to science and technology conferences, (9), 123-125.

11. Baigurin, Zh. D., Kozhaev, Zh. T., Imansakipova, Z. B., \& Spitsyn, A. A. (2016). Technique of zone division of surface of the ore deposit by the degree of potential caving risk. In Collected papers of the $2^{\text {nd }}$ international school of thought of Academician K. N. Trubetskoi "Problems and prospects of integrated development and preservation of the earth interior". Retrieved from http://xn--80apgmbdfl.xn--plai/?page_id=2352. 
12. Imansakipova, B. B., Kozhaev, Zh. T., \& Spitsyn, A.A. (2017). Technique of revealing weakened zones on the surface of the deposit. In The $2^{\text {nd }}$ international science and technology Internet conferences "Innovational development of mining industry". Retrieved from http://www.knu.edu.ua/storage/files/2/ Naýka/Konferentsii/rozvitok\%202017/tezısy\%20konferents11. pdf.

13. Altaeva, A. A., Imansakipova, B. B., Kozhaev, Zh. T., Sadykov, B. B., \& Spitsyn, A. A. (2018). Improvement of the energy criterion when zoning the earth's surface by the degree of weakening. Vestnik KazNITU, (4), 32-38.

14. Kolesnikov, I. Yu., Morozov, V. N., Tatarinov, V. N., \& Tatarinova, T.A. (2017). Strained-deformed energy zoning of geological environments to locate ecological infrastructure objects. Innovatics and Expert Examination, 2(20), 77-88.

15. Bychkov, S. V. (2018). A model of a source of sudden rock and gas outburst from the rock massif. Bulletin of Research Center for Safety in Coal Industry, (4), 80-89.

16. Gazenaur, N. V. (2016). Energy criteria of optimization of optical capsule. Actualscience, 2(9), 31-35.

17. Spiridonova, V. V. (2016). Complex zoning of the territory of Severo-Kavkazskii economic region according to natural and technology-related risks. Mine surveying and subsurface use, 4(84), 7-13.

18. Erasov, V.S., \& Oreshko, E. I. (2017). Power, deformation and energy criteria of damage. Trudy VIAM, (10), 97-111. https://doi.org/10.18577/2307-6046-2017-0-10-11-11.

19. Sulaimon, A. A., \& Teng, L. L. (2019). Modified approach for identifying weak zones for effective sand management. Journal of Petroleum Exploration and Production Technology, 9, 1-19. https://doi.org/10.1007/s13202-019-00784-5.

\section{Новий підхід до зонального районування поверхні родовища за ступенем провалонебезпеки}

\section{Б. Б. Садиков ${ }^{1}$, Ж. Д. Байгурін ${ }^{1}$, А. А. Алтаєва ${ }^{2}$,} Ж. Т. Кожаєв ${ }^{3}$, В. Стеллінг ${ }^{4}$

1 - Сатпаєв Університет, м. Алмати, Республіка Казахстан, e-mail: batyrkhan_sadykov@mail.ru

2 - Інститут гірничого справи імені Д.А. Кунаєва, м. Алмати, Республіка Казахстан, e-mail: a.aselya_92@mail.ru

3 - Казахський національний університет імені альФарабі, м. Алмати, Республіка Казахстан

4 - Технічний університет Георга Агріколи, м. Бохум, Німеччина

Мета. Розробка нового методу зонального районування поверхні родовища за ступенем ослаблення порід, в основі якого лежить енергетичний критерій, що визначається різницею потенційної енергії тяжіння елемента гірського масиву між станами нестійкої та стійкої рівноваги

Методика. Застосовані експериментальні графоаналітичні методи, а також математичне моделювання.

Результати. Запропоновано метод зонального районування земної поверхні родовища за ступенем провалонебезпеки, з урахуванням тріщинуватості гірських порід і розподілу гірського тиску у взаємозв'язку з рельєфом місцевості. Виконана верифікація результатів аналізу раніше використаних методів і теоретичних положень щодо обгрунтування анізотропії щільності гірського ма- сиву. Новий метод визначення напружено-деформованого стану масиву враховує анізотропію його щільності

Наукова новизна. Розроблено новий метод визначення напружено-деформованого стану гірського масиву через різницю геоенергії між станом стійкої та нестійкої рівноваги елемента масиву.

Практична значимість. Розроблений метод дозволив підвищити точність побудови ситуаційної карти районування родовища за енергетичним критерієм на 15-20\%.

Ключові слова: геомоніторинг, космічна радіолокаційна інтерферометрія, цифрова карта, критерій зонування, потенційна енергія

\section{Новый подход к зональному районированию поверхности месторождения по степени провалоопасности}

\author{
Б. Б. Садыков ${ }^{1}$ Ж. Д. Байгурин ${ }^{1}$, А. А. Алтаева ${ }^{2}$, \\ Ж. Т. Кожаев ${ }^{3}$, В. Стеллиг
}

1 - Сатпаев Университет, г. Алматы, Республика Казахстан, e-mail: batyrkhan sadykov@mail.ru

2 - Институт горного дела имени Д. А. Кунаева, г. Алматы, Республика Казахстан, e-mail: a.aselya_92@mail.ru

3 - Казахский национальный университет имени альФараби, г. Алматы, Республика Казахстан

4 - Технический университет Георга Агриколы, г. Бохум, Германия

Цель. Разработка нового метода зонального районирования поверхности месторождения по степени ослабленности пород, в основе которого лежит энергетический критерий, определяемый разностью потенциальной энергии тяготения элемента горного массива между состояниями неустойчивого и устойчивого равновесия.

Методика. Применены экспериментальные графоаналитические методы, а также математическое моделирование.

Результаты. Предложен метод зонального районирования земной поверхности месторождения по степени провалоопасности, с учетом трещиноватости горных пород и распределения горного давления во взаимосвязи с рельефом местности. Выполнена верификация результатов анализа ранее использованных методов и теоретических положений по обоснованию анизотропии плотности горного массива. Новый метод определения напряженно-деформированного состояния массива учитывает анизотропию его плотности.

Научная новизна. Разработан новый метод определения напряженно-деформированного состояния горного массива через разность геоэнергии между состоянием устойчивого и неустойчивого равновесия элемента массива.

Практическая значимость. Разработанный метод позволил повысить точность построения ситуационной карты районирования месторождения по энергетическому критерию на $15-20 \%$.

Ключевые слова: геомониторинг, космическая радиолокационная интерферометрия, цифровая карта, критерий зонирования, потенциальная энергия

Recommended for publication by Kh.M. Kasimkhanova, Doctor of Technical Sciences. The manuscript was submitted 25.03.19. 